\title{
COMPARISON OF AVAILABLE WATER RESOURCES FOR IRRIGATION IN MITHAWAN HILL TORRENT COMMAND AREA OF DERA GHAZI KHAN, PAKISTAN
}

\author{
Matlob Ahmad ${ }^{1, *}$, Muhammad Arshad ${ }^{1}$, M. Jehanzeb Masud Cheema ${ }^{1}$ and $\operatorname{Riaz}_{\text {Ahmad }}{ }^{2}$ \\ ${ }^{1}$ Department of Irrigation and Drainage, University of Agriculture, Faisalabad, Pakistan; \\ ${ }^{2}$ Department of Agronomy, University of Agriculture, Faisalabad, Pakistan. \\ "Corresponding author's e-mail: machangwani@ hotmail.com
}

\begin{abstract}
Pakistan is facing a shortage of water for many years, mainly due to increase in population and mismanagement of available water resources. There is average annual potential of 23 billion $\mathrm{m}^{3}$ in hill torrent water resources of the country, which has not yet been utilized to its productive potential. This study compared the irrigation practices, crop yield, water productivity and benefit cost ratio of spate irrigated crops with other available sources of irrigation in Mithawan hill torrent command area of Dera Ghazi Khan, Pakistan. The data were collected through field visits/observations, farmers' interviews, and from the relevant organizations. CROPWAT model was used to determine crops water requirements for assessment of irrigation efficiencies while SPSS software was used for descriptive statistics of the study data. The cropping intensities in the study area during wet and dry years were 90 and $70 \%$, respectively, with an average of $80 \%$. The spate irrigated fields were applied $1.05 \mathrm{~m}$ depth of water at once in a season that had an average application efficiency of $28 \%$ whereas, the efficiency of canal water and groundwater applied separately or conjunctively varied from 24 to $86 \%$ with an average of $52 \%$. The water productivity of spate irrigated crops varied from 0.08 to $0.19 \mathrm{~kg} / \mathrm{m}^{3}$ while canal water and/or groundwater irrigated crops cultivated in the study area varied from 0.27 to $3.28 \mathrm{~kg} / \mathrm{m}^{3}$. Normally, cotton was cultivated with canal water and onion with groundwater that had water productivity of 0.27 and $3.28 \mathrm{~kg} / \mathrm{m}^{3}$, respectively. The benefit cost ratio of spate irrigated crops varied from 1.49 to 2.39 , while for irrigated with canal water and/or groundwater it varied from 1.29 to 1.57. Based on the result of this study, it may be concluded that the efficient utilization of hill torrents for spate irrigation would improve the copping intensities, crop yield, water productivity and socioeconomic conditions of the farmers of study area. Also, the efficient utilization of hill torrent water for spate irrigation would minimize the dependence on canal water and groundwater in the study area.
\end{abstract}

Keywords: Spate irrigation, cropping intensity, irrigation efficiency, water productivity, benefit cost ratio

\section{INTRODUCTION}

Pakistan is the second largest country in South Asia by size with a total area of $79.61 \mathrm{mha}$ and population 184.35 million (Wasti, 2013). The potential area for agriculture and forestry is estimated as $46 \%$ (36.62mha) of the total area of country (Hasan, 2008). The average annual cultivated area of the country was $25.72 \mathrm{mha}$, out of which, about $19.27 \mathrm{mha}$ was under full control of irrigation (i.e. $6.91 \mathrm{mha}$ canal irrigated, $4.13 \mathrm{mha}$ groundwater irrigated, $7.96 \mathrm{mha}$ combined with canal water and groundwater, and $0.27 \mathrm{mha}$ irrigated with wastewater), $2 \mathrm{mha}$ by the spate irrigation, $3.2 \mathrm{mha}$ rainfed (Barani) and 1.25mha was sailaba riverine (Ahmad, 2007; Baig et al., 2013; Frenken, 2012). So far, there are enough land resources to meet the grain demand of increasing population but there is shortage of water. Pakistan is facing the shortage of water for many years, mainly due to increase in population and mismanagement of available water resources. The increase in population of country has decreased the surface water supplies from $5260 \mathrm{~m}^{3} /$ capita in 1951 to $1032 \mathrm{~m}^{3} / \mathrm{capita}$ in 2013 (WAPDA, 2013). In addition to the increase in population, other factors, such as lack of storage facilities, inefficient canal system, water losses through distributaries, wastage of water at the farm level and mismanagement of hill torrents are also responsible for water scarcity in the country.

Spate irrigation, which is accomplished by the supply of water from hill torrent, is the second largest source of irrigation after canal water irrigation in Pakistan. This system of irrigation prevails in the country since centuries. Spate irrigation system is participatory in nature and environment friendly as it does not require energy due to gravity flow and has organic farming produce. The presence of heavy sediments in hill torrent flow also plays an important role in agricultural production. There is the average annual potential of around 23 billion $\mathrm{m}^{3}$ of water from 14 major hill torrents (Sufi et al., 2011). Out of these, 13 hill torrents (excluding Kharan Closed Basin Hill Torrent Areas) have great potential for land and water resources development at about 1204 conservation sites. The highest potential for hill torrent management exists in Balochistan, whereas, the other potential hill torrents include DG Khan, DI Khan, Bannu, Hazara, Kachhi Basin, 
Kirther Range, Karachi area, Sehwan, Petaro (Ahmad, 2012). A major part of about $13.25 \mathrm{mha}$ of potential land, out of which $6.35 \mathrm{mha}$ lying in the hilly areas and $6.9 \mathrm{mha}$ in the foothills/plains, can be brought under cultivation through efficient utilization of hill torrents water. Depending upon the occurrence of hill torrents and their management, however, only 0.72 to $2.0 \mathrm{mha}$ of land is annually cultivated with spate irrigation, which makes about $9 \%$ of the total annually irrigated area of Pakistan (Mirjat et al., 2011). The scarce water resources of the country including canal water and groundwater alone cannot meet the future water requirements without managing the hill torrent water resources to its productive potential.

But there is temporal and spatial variability in the rainfall, which may result an uncertainty of spate irrigation at the time of sowing (Javed et al., 2007). The irrigation with groundwater is most reliable that permits the farmers to timely sow crops and provides subsequent irrigations. To ensure water availability at the time of sowing, therefore farmers in Mithawan hill torrent command area, Dera Ghazi Khan (DG Khan) have installed pumping units for lifting groundwater and canal water for irrigation (where feasible). They have a choice to use either canal water, groundwater or hill torrent water separately or conjunctively. The efficient utilization of hill torrent water for spate irrigation will not only reduce the dependence on groundwater and canal water but also cut down energy cost in the study area. Therefore, the study was conducted to compare the irrigation practices, crop yield, water productivity and benefit cost ratio (BCR) of spate irrigated crops with other available sources of irrigation for better planning of water resources in the study area. The results of study may be considered for future planning of water resources in similar spate irrigated areas.

\section{MATERIALS AND METHODS}

Study area: The research was conducted at Mithawan hill torrent command area of DG Khan District, Punjab, Pakistan during the cropping year 2012-13 and 2013-14. The study area is located in Pachadh Area that lies between Suleiman Mountains and Kachhi Canal, and falls under the administrative control of DG Khan District. The study area lies between latitude $29.731^{\circ} \mathrm{N}$ to $29.862^{\circ} \mathrm{N}$ and longitude $70.314^{\circ} \mathrm{E}$ to $70.487^{\circ} \mathrm{E}$ as shown in Figure 1 . The total area under this torrent is about $16000 \mathrm{ha}$, which has arid climate and erratic rainfall pattern, and received 25 years return period discharge of $2210 \mathrm{~m}^{3} / \mathrm{s}$ (I\&PD, 2002).

Irrigation practices and water rights: In the study area, agriculture is mainly dependent on hill torrent/rainfall. In the absence of spate water at the time of cultivation, crops are grown with groundwater and/or lifting canal water. The farmers construct earthen embankments around the fields to store the hill torrent water into it, which is locally called as bund. To divert water into the bunds, farmers construct an earthen diversion structure across the flow of torrent. These earthen diversion structures may be constructed by the individual or group of farmers to make the hill torrent flow available for irrigation of bund(s). The irrigation turn system starts from upper to lower riparian, without consideration of duration and magnitude of flow. After the successful application of water, the upstream farmer cuts the diversion structure and let the water move down. Then downstream farmers divert the water into their bunds with the help of already constructed diversion structures in the torrent channel. Upon drying up water in bund, crops are sown which flourish on the moisture stored in soil. There is no further irrigation application except rains. However, the farmers whose landholding is adjacent to right bank of DG Canal have installed pumps for lifting canal water for the cultivation of crops. Similarly, some farmers at the middle and tail of command area have installed tube wells for cultivation/irrigation of crops with groundwater in the absence or shortage of spate water.

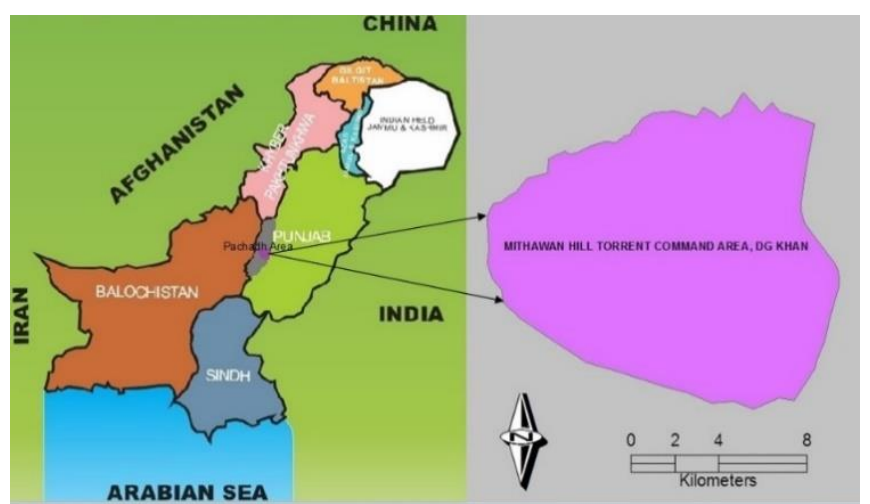

Figure 1. Location of the Mithawan hill torrent command area, DG Khan.

Cropping pattern: The cropping pattern of study area varies with the occurrence of hill torrent and its management for irrigation application. During the year 2012, a large number of hill torrents occurred, which were utilized by the majority of famers for spate irrigation. So, the year 2012 was considered a wet year. Whereas, in 2013, about 4 to 5 times hill torrent occurred for a short duration with low discharge, which could not be utilized by the large number of farmers and thus, it was considered a dry year. Cotton, maize, sorghum, millet and guar were sown during Kharif season while wheat, tobacco, sunflower, gram, brassica and arugula during the Rabi season. However, onion and fodder were cultivated in both the seasons. Out of aforementioned crops, cotton, wheat, onion, maize and fodders were irrigated by the canal water and groundwater separately or conjunctively. Whereas sorghum, millet and guar/cluster bean were sown through the spate irrigation that was applied once before the sowing of crop, while the successive crop water requirement was satisfied by the rainfall, if any. 
Data collection: The data were collected for the cropping year 2012-13 and 2013-14. A reconnaissance survey of study area was conducted through farmers' interviews. For this, fifty randomly selected farmers were interviewed, which were representing the landholdings of about $10 \%$ of total landholding of the study area. The data collected through farmers' interviews included landholding, field/bund size, crops sown, sources of irrigation, hill torrent water application, type of pumps, power source, number and duration of irrigation application, crop inputs, cultural practices, yield of crop, price of yield, etc. In order to determine the volume of water applied to the fields, discharge of irrigation pumps were measured using cut-throat flume of 10x90cm size.

CROPWAT model was used to calculate the crop water requirement $(\mathrm{CWR})$. The model allows the development of improved irrigation practices, planning of irrigation schemes under varying water supply conditions and assessment of production under rainfed or deficit irrigation conditions (Arnold, 2006). The calculation of CWR was carried out by calling up successively the appropriate climate and rainfall data sets, together with the crop files and the corresponding planting dates. Once all the data were entered, CROPWAT Windows automatically calculated the results. The climatic data on rainfall, temperatures (minimum \& maximum), relative humidity, wind speed and sunshine hours required for model application were obtained from Pakistan Meteorological Department (Meteorological Observatory at DG Khan).

The benefit cost ratio of the crops cultivated in the study area was calculated by dividing the sum of all benefits/income with sum of investment on the crops. The total investment on crop was consisted of the cost of inputs, labor and machinery (seed, irrigation, fertilizer, pesticides, seed bed preparation, labor of harvesting, threshing, material handling, transportation etc.). While the benefit/income obtained from the crop was included price of yield and by-products.

\section{RESULTS AND DISCUSSION}

Cropping pattern and cropping intensity: The cropping pattern of study area during Kharif season, 2012 and 2013 is given in Table 1.

Table 1. Cropping pattern of Kharif season.

\begin{tabular}{lcc}
\hline Crop & $\begin{array}{c}\text { Kharif, 2012 } \\
\text { (\% of total area) }\end{array}$ & $\begin{array}{c}\text { Kharif, 2013 } \\
\text { (\% of total area) }\end{array}$ \\
\hline Cotton & 13.07 & 13.90 \\
Onion & 4.61 & 7.50 \\
Maize & 0.16 & 0.23 \\
Sorghum & 6.18 & 1.73 \\
Millet & 5.73 & 1.19 \\
Guar & 0.76 & 0.61 \\
Fodders & 0.14 & 0.41 \\
Total & 30.65 & 25.57 \\
\hline
\end{tabular}

Cotton was the major crop of Kharif season and it was cultivated on about 13 and $14 \%$ of the total command area during 2012 and 2013, respectively. While the other crops namely; onion, maize, sorghum, millet, guar and fodder were cultivated on $4.61,0.16,6.18,5.73,0.76,0.14$ and $7.5,0.23$, $1.73,1.19,0.61,0.41 \%$ of the total area during 2012 and 2013 , respectively. The comparison indicates that the area under cultivation of cotton, guar, maize and fodder was almost same during the wet and dry years while onion crop cultivation was less during the wet year and high during the dry year. The less cultivation of onion during the wet year was due to the diversion of farmers from onion to spate irrigated crops. Accordingly, the area under the cultivation of sorghum and millet was higher during the wet year and low during the dry year. It indicates that the farmers preferred the cultivation of spate irrigated crops during the wet year. The cropping pattern of study area during Rabi season, 2012-13 and 2013-14 is given in Table 2.

Table 2. Cropping pattern of Rabi season.

\begin{tabular}{lcc}
\hline Crop & $\begin{array}{c}\text { Rabi, 2012-13 } \\
(\% \text { of total area })\end{array}$ & $\begin{array}{c}\text { Rabi, 2013-14 } \\
(\% \text { of total area })\end{array}$ \\
\hline Wheat & 23.02 & 37.40 \\
Onion & - & 0.47 \\
Tobacco & 0.64 & 0.36 \\
Sunflower & 0.71 & 0.55 \\
Gram & 28.71 & 1.59 \\
Brassica & 3.62 & 0.84 \\
Arugula & 0.73 & 0.07 \\
Fodders & 0.86 & 1.38 \\
Total & 58.29 & 42.66 \\
\hline
\end{tabular}

Wheat and gram were grown on about 23 and $29 \%$ of the total study area during Rabi season, 2012-13 and on about 37 and $2 \%$ during 2013-14, respectively. Brassica was cultivated on 3.62 and $0.84 \%$ of the total command area during Rabi season, 2012-13 and 2013-14, respectively. Similarly, fodder was cultivated on 0.86 and $1.38 \%$ of the total command area during Rabi season, 2012-13 and 2013-14, respectively. The all other crops namely; onion, tobacco, sunflower, and arugula were cultivated on less than $1 \%$ of the total command area during Rabi season of both cropping years. The comparison indicates that the area under wheat cultivation was quite less during the wet year and more during the dry year. While the area under cultivation of gram, brassica and arugula was relatively high during the wet year than dry year. The less cultivation of wheat during the wet year was due to more cultivation of gram, brassica and arugula by the spate irrigation. Out of spate irrigated crops, gram was cultivated on major part of cultivated area during the Rabi season of wet year 2012-13.

Table 3 shows that the seasonal cropping intensities for Kharif and Rabi seasons were 30.91 and $59.37 \%$ during the cropping year, 2012-13, and 26.04 and $43.44 \%$ during the cropping 
year, 2013-14, respectively. There was a less difference of area under cultivation $(<5 \%)$ during Kharif season of wet and dry year but a significant difference of area under cultivation (about 16\%) was found during Rabi season of wet and dry year. The significant difference in cropping intensities during Rabi seasons was due to more cultivation of spate irrigated crops during the wet year than that of a dry year. The annual cropping intensity of wet year was about $90 \%$ as compared to $70 \%$ of dry year. However, the average cropping intensity of the selected hill torrent command area was found $80 \%$, which was far less than that of the average cropping intensity (173\%) of irrigated areas of Punjab (Raza et al., 2009).

Table 3. Cropping intensity during wet and dry year.

\begin{tabular}{lc}
\hline Cropping season/year & Cropping intensity (\%) \\
\hline Kharif, 2012 & 30.91 \\
Rabi, 2012-13 & 59.37 \\
Annual 2012-13 & 90.28 \\
Kharif, 2013 & 26.04 \\
Rabi, 2013-14 & 43.44 \\
Annual 2013-14 & 69.48 \\
Average annual & 79.88 \\
\hline
\end{tabular}

Sources of irrigation and their relative contribution: The access of different available sources of irrigation to the farmers of study area is given in Table 4 which shows that $14 \%$ of the farmers had opportunity of using hill torrent water for irrigation and $4 \%$ each for groundwater and canal water. Forty four percent of the farmers had the facility to use hill torrent plus groundwater, $2 \%$ hill torrent plus canal water, and $32 \%$ had access to all water sources. It indicates that overall $92 \%$ of the farmers had the availability of hill torrent flow and remaining $8 \%$ had no access to the hill torrent flow due to either non-existence of channel system or sand dunes. Similarly, $80 \%$ of the famers of study area had the opportunity of groundwater extraction and $38 \%$ of farmers had access to the canal water lift irrigation. Canal water lift irrigation could be availed only by the farmers located adjacent to the right bank of DG Canal. Generally, all the farmers prefer to use hill torrent flow for spate irrigation when available. However, farmers are forced to use canal water and/or groundwater to cultivate crops in case of non-occurrence of hill torrents. The farmers who had access to both the canal water and groundwater, they preferred to use canal water because of good quality and low energy cost. Consequently, the priority of irrigation water application was found to be hill torrent, canal water and groundwater. Therefore, the efficient utilization of hill torrent for irrigation would attract farmers to bring more area under cultivation.

As shown in Table 5, about $88 \%$ of farmers could control and divert the hill torrents for spate irrigation, while $12 \%$ of the farmers could not use the hill torrent flow for spate irrigation. The reasons for the farmers not using spate water were one or more such as failure of diversion structures due to high discharge, non-existence of channel network, deprivation by the influential and lack of financial resources for making diversion structures. Mostly, the land area of farmers who faced aforementioned constraints remained uncultivated in the study area.

Table 4. Sources of irrigation available to the farmers of study area.

\begin{tabular}{lcc}
\hline Source(s) of irrigation & $\begin{array}{c}\text { No. of } \\
\text { respondents }\end{array}$ & $\begin{array}{c}\text { Percent of } \\
\text { total farmers }\end{array}$ \\
\hline Hill torrents (HT) & 07 & 14 \\
Groundwater (GW) & 02 & 04 \\
Canal water (CW) & 02 & 04 \\
Hill torrents + groundwater & 22 & 44 \\
Hill torrents + canal water & 01 & 02 \\
All sources (HT+CW+GW) & 16 & 32 \\
Total & 50 & 100 \\
\hline
\end{tabular}

Table 5. Use of hill torrent spate irrigation and depth of water applied in the bund.

\begin{tabular}{lcc}
\hline Hill torrent & $\begin{array}{c}\text { Used for } \\
\text { irrigation }\end{array}$ & $\begin{array}{c}\text { Unable to } \\
\text { use }\end{array}$ \\
\hline No. of respondents & 44 & 6 \\
Percent of respondents & 88 & 12 \\
Min. depth (m) & 0.61 & - \\
Max. depth (m) & 1.68 & - \\
Mean depth (m) & 1.05 & - \\
\hline
\end{tabular}

The farmers who were recipient of hill torrent flow diverted 0.61 to $1.68 \mathrm{~m}$ depth of water into their fields. On an average, $1.05 \mathrm{~m}$ depth of water was applied into the bunds while the successive crop water requirement was satisfied by the rainfall, if any. Thus, apart from direct rainfall, the spate irrigated crops were applied $10500 \mathrm{~m}^{3} /$ ha of water in a season. Under the existing scenario, the overall application efficiency of spate irrigation was determined as $28 \%$ (Ahmad and Choudhry, 2005). The volume of water applied to the crops other than spate irrigation included canal water and groundwater, whereas the total water available may include effective rainfall as well. Table 6 shows the total volume of water applied/available to canal water and groundwater irrigated crops cultivated in the study area.

The results of total water available to crops were utilized to assess the relative contribution of available sources of irrigation to canal water and groundwater separately or conjunctively irrigated crops of the study area. Table 7 gives the detail of percentage of water applied through different sources to the crops cultivated by the canal water and/or groundwater in the study area. However, the mean relative contribution of canal water, groundwater and direct rainfall to crop water requirement was 28,61 and $11 \%$, respectively. The results indicate that the maximum crop water requirement was satisfied by the groundwater irrigation. If, hill torrent water is not efficiently utilized for spate irrigation, in future, 
the current rate of groundwater abstraction would lower the watertable to a serious level. Therefore, to avoid the decline of watertable in study area, there is dire need to efficiently utilize the hill torrent water for spate irrigation.

Table 6. Irrigation water available to the crops through different sources.

\begin{tabular}{|c|c|c|c|c|}
\hline Crop & $\begin{array}{c}\text { Canal } \\
\text { water } \\
\text { (m³/ha) }\end{array}$ & $\begin{array}{c}\text { Groundw } \\
\text { ater } \\
\left(\mathbf{m}^{3} / \mathbf{h a}\right)\end{array}$ & $\begin{array}{c}\text { Effective } \\
\text { rainfall } \\
\left(\mathrm{m}^{3} / \mathrm{ha}\right)\end{array}$ & $\begin{array}{c}\text { Total } \\
\left.\text { ( } \mathrm{m}^{3} / \mathbf{h a}\right)\end{array}$ \\
\hline Wheat & 1266 & 3521 & 425 & 5212 \\
\hline Cotton & 4008 & 4485 & 1366 & 9860 \\
\hline Onion & 1252 & 5108 & 1208 & 7569 \\
\hline Sunflower & 2572 & 2857 & 467 & 5896 \\
\hline Tobacco & 0 & 5871 & 451 & 6322 \\
\hline Maize & 3674 & 1859 & 763 & 6295 \\
\hline Fodder & 1060 & 5022 & 844 & 6926 \\
\hline
\end{tabular}

Table 7. Water applied to the crops through different sources.

\begin{tabular}{lccc}
\hline Crop & $\begin{array}{c}\text { Canal water } \\
(\boldsymbol{\%})\end{array}$ & $\begin{array}{c}\text { Ground water } \\
(\boldsymbol{\%})\end{array}$ & $\begin{array}{c}\text { Rainfall } \\
(\boldsymbol{\%})\end{array}$ \\
\hline Wheat & 24 & 68 & 08 \\
Cotton & 41 & 45 & 14 \\
Onion & 17 & 67 & 16 \\
Sunflower & 44 & 48 & 08 \\
Tobacco & 00 & 93 & 07 \\
Maize & 58 & 30 & 12 \\
Fodder & 15 & 73 & 12 \\
Overall average & 28 & 61 & 11 \\
\hline
\end{tabular}

Irrigation efficiency: The amount of water lost or saved by the farmers of study area in contrast with recommended efficiencies described by the FAO in "Irrigation Water Management: Irrigation Scheduling Training Manual No. 4" is given in Table 8 .

The irrigation efficiency of the study area was $37,76,46,86$, 56,24 and $41 \%$ for wheat, cotton, onion, sunflower, tobacco, maize and fodder, respectively, with an overall farm irrigation efficiency of $52 \%$. Twenty percent of water to be applied to the crop was lost due to over irrigation of wheat, $90 \%$ for maize and $10 \%$ for fodder. Similarly, $41 \%$ of the water to be applied to the crop was saved due to under irrigation of cotton, $2 \%$ in onion, $48 \%$ in sunflower and $20 \%$ in tobacco cultivation. The loss of water was found in basin method of irrigation while saving was found in crops, which were cultivated by furrow method of irrigation. Thus, it was concluded that the farmers lost water in basin method but saved in furrow method of irrigation.

Crop yield: The yield of various crops cultivated by the farmers of study area is given in Table 9.

Table 9. Yields of various crops at the study area.

\begin{tabular}{lcrrr}
\hline Crop & $\begin{array}{c}\text { No. of } \\
\text { respondents }\end{array}$ & $\begin{array}{c}\text { Min. } \\
\text { (kg/ha) }\end{array}$ & $\begin{array}{c}\text { Max. } \\
\text { (kg/ha) }\end{array}$ & \multicolumn{1}{c}{$\begin{array}{c}\text { Mean } \\
\text { (kg/ha) }\end{array}$} \\
\hline Cotton & 07 & 1483 & 2718 & 2291 \\
Wheat & 26 & 1977 & 4942 & 3848 \\
Onion & 11 & 12602 & 27181 & 20849 \\
Gram & 31 & 618 & 3954 & 1991 \\
Sorghum & 23 & 741 & 3954 & 1693 \\
Millet & 17 & 618 & 1977 & 1365 \\
Brassica & 11 & 247 & 1112 & 813 \\
Arugula & 02 & 741 & 1112 & 927 \\
Guar & 02 & 432 & 1483 & 958 \\
\hline
\end{tabular}

The average yields of cotton, wheat, onion, gram, sorghum, millet, brassica, arugula and guar cultivated by the farmers in study area were 2291, 3848, 20849, 1991, 1693, 1365, 813, 927 and $958 \mathrm{~kg} / \mathrm{ha}$, respectively. Only one farmer cultivated sunflower crop but was unable to respond the yield of sunflower. While the average yields of cotton, wheat, gram, sorghum, millet, brassica and guar obtained from other spate irrigated areas of the country were 490, 1078, 789, 455, 564, 760 and $692 \mathrm{~kg} / \mathrm{ha}$, respectively (Steenbergen et al., 2008). The average yields of crops obtained from other spate irrigated area of Pakistan was less than that of the study area. In Pakistan, the overall yields of cotton, wheat, onion, gram, sorghum, millet, brassica and rapeseed/mustard were 773 , 2797, 12999, 487, 601, 634, 1040 and 914kg/ha, respectively (Wasti, 2014), which were also less as compared to the yield of crops obtained from the study area. The yields of sorghum, millet, gram, oilseeds and wheat found by Ahmad and Choudhry (2005) in the study area were 565, 520, 576, 562 and $1230 \mathrm{~kg} / \mathrm{ha}$, respectively. The results indicate that the

Table 8. Irrigation efficiency (distribution and application) in the study area.

\begin{tabular}{|c|c|c|c|c|c|}
\hline Crop & $\begin{array}{c}\text { Irrigation required } \\
\left(\mathrm{m}^{3} / \mathrm{ha}\right)\end{array}$ & $\begin{array}{c}\text { Irrigation applied } \\
\left(\mathrm{m}^{3} / \mathrm{ha}\right)\end{array}$ & $\begin{array}{c}\text { Irrigation } \\
\text { efficiency }(\%)\end{array}$ & $\begin{array}{l}\text { Irrigation to be } \\
\text { applied (m³/ha) }\end{array}$ & $\begin{array}{c}\text { Irrigation } \\
\text { adequacy }(\%)\end{array}$ \\
\hline Wheat & 1794 & 4787 & 37 & 3987 & +20 \\
\hline Cotton & 6471 & 8493 & 76 & 14380 & -41 \\
\hline Onion & 2909 & 6361 & 46 & 6463 & -02 \\
\hline Sunflower & 4677 & 5429 & 86 & 10392 & -48 \\
\hline Tobacco & 3229 & 5738 & 56 & 7174 & -20 \\
\hline Maize & 1314 & 5533 & 24 & 2919 & +90 \\
\hline Fodder & 2490 & 6082 & 41 & 5534 & +10 \\
\hline
\end{tabular}


yield of spate irrigated crops had huge variation between 2005 and 2012-14. This difference in yield could be the result of occurrence of hill torrent, its management and rainfall for subsequent irrigation water requirement of the crops during the specific years. It means that the study area has great agricultural production potential. If, hill torrents for spate irrigation are efficiently utilized then more yield may be obtained than that of other irrigated areas of Pakistan. The graphical presentation of yield comparison for various crops is given in Fig. 2.

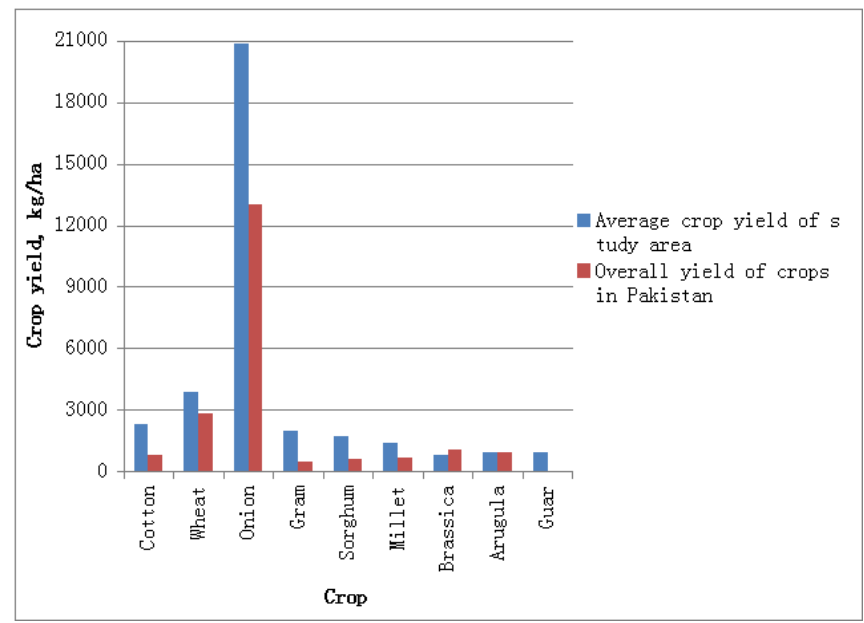

Figure 2. Comparison of crops yields of study area and overall in Pakistan.

Water Productivity: The water productivity of crops cultivated in the study area is given in Table 10.

Table 10. Water productivity of Mithawan hill torrent command area.

\begin{tabular}{|c|c|c|c|}
\hline Crop & $\begin{array}{c}\text { Yield } \\
\text { (kg/ha) }\end{array}$ & $\begin{array}{c}\text { Volume of } \\
\text { water applied } \\
\left(\mathrm{m}^{3} / \mathbf{h a}\right)\end{array}$ & $\begin{array}{c}\text { Water } \\
\text { productivity } \\
\left(\mathbf{k g} / \mathrm{m}^{\mathbf{3}}\right)\end{array}$ \\
\hline Cotton & 2291 & 8493 & 0.27 \\
\hline Wheat & 3848 & 4787 & 0.80 \\
\hline Onion & 20849 & 6361 & 3.28 \\
\hline Gram & 1991 & 10475 & 0.19 \\
\hline Sorghum & 1693 & 10475 & 0.16 \\
\hline Millet & 1365 & 10475 & 0.13 \\
\hline Brassica & 813 & 10475 & 0.08 \\
\hline Arugula & 927 & 10475 & 0.09 \\
\hline Guar & 958 & 10475 & 0.09 \\
\hline
\end{tabular}

The water productivity of canal water and/or groundwater irrigated crops namely; onion, cotton and wheat were 3.28, 0.27 and $0.80 \mathrm{~kg} / \mathrm{m}^{3}$, respectively. More water productivity of onion was mainly due to high yield not because of the efficient use of irrigation. While, all spate irrigated crops namely; gram, sorghum, millet, brassica, arugula and guar had water productivity of $0.19,0.16,0.13,0.08,0.09$ and $0.09 \mathrm{~kg} / \mathrm{m}^{3}$, respectively. The low water productivity of spate irrigated crops was due to excessive ponding $(0.61-1.68 \mathrm{~m})$ in case of spate water and low yield than potential due to various stresses during crop growth period. The water productivity of spate irrigated crops can be increased by applying only required amount of water and conserving moisture in the field for long time. Thus, there is need to determine the depth of water to be applied to the bund for efficient use of spate water, improve water productivity and bring more area under cultivation.

Benefit cost ratio of the crops: Table 11 shows the cost of production for various crops cultivated in the study area.

Table 11. Investment of the farmers for cultivation of crops.

\begin{tabular}{|c|c|c|c|c|}
\hline Crop & $\begin{array}{c}\text { No. of } \\
\text { respondents }\end{array}$ & $\begin{array}{c}\text { Min. } \\
\text { (Million } \\
\text { Rs./ha) }\end{array}$ & $\begin{array}{l}\text { Max. } \\
\text { (Million } \\
\text { Rs./ha) }\end{array}$ & $\begin{array}{l}\text { Mean } \\
\text { (Million } \\
\text { Rs./ha) }\end{array}$ \\
\hline Cotton & 07 & 0.094 & 0.122 & 0.105 \\
\hline Wheat & 26 & 0.056 & 0.096 & 0.078 \\
\hline Onion & 11 & 0.213 & 0.361 & 0.297 \\
\hline Gram & 31 & 0.027 & 0.063 & 0.040 \\
\hline Sorghum & 23 & 0.018 & 0.046 & 0.029 \\
\hline Millet & 17 & 0.018 & 0.033 & 0.025 \\
\hline Brassica & 11 & 0.013 & 0.034 & 0.024 \\
\hline Arugula & 02 & 0.020 & 0.027 & 0.024 \\
\hline Guar & 02 & 0.020 & 0.068 & 0.044 \\
\hline
\end{tabular}

The average cost of production was assessed as; cotton Rs. 0.105, wheat Rs. 0.078, onion Rs. 0.297, gram Rs. 0.040, sorghum Rs. 0.029, millet Rs. 0.025, brassica Rs. 0.024, arugula Rs. 0.024 and guar Rs. 0.044 million per hectare. The investment on canal water and/or groundwater irrigated crops was higher than that of spate irrigated crops. Table 12 shows the income from the crops cultivated in the study area.

Table 12. Income from the crops cultivated in the study area.

\begin{tabular}{lcccc}
\hline Crop & $\begin{array}{c}\text { No. of } \\
\text { respondents }\end{array}$ & $\begin{array}{c}\text { Min. } \\
\text { (Million } \\
\text { Rs./ha) }\end{array}$ & $\begin{array}{c}\text { Max. } \\
\text { (Million } \\
\text { Rs./ha) }\end{array}$ & $\begin{array}{c}\text { Mean } \\
\text { (Million } \\
\text { Rs./ha) }\end{array}$ \\
\hline Cotton & 07 & 0.093 & 0.164 & 0.136 \\
Wheat & 26 & 0.058 & 0.156 & 0.116 \\
Onion & 11 & 0.265 & 0.625 & 0.468 \\
Gram & 31 & 0.018 & 0.156 & 0.079 \\
Sorghum & 23 & 0.039 & 0.157 & 0.070 \\
Millet & 17 & 0.015 & 0.065 & 0.041 \\
Brassica & 11 & 0.015 & 0.081 & 0.042 \\
Arugula & 02 & 0.028 & 0.044 & 0.036 \\
Guar & 02 & 0.026 & 0.212 & 0.119 \\
\hline
\end{tabular}

The average income from crops obtained by the farmers of study area were cotton Rs. 0.136 , wheat Rs. 0.116 , onion Rs. 
0.468, gram Rs. 0.079, sorghum Rs. 0.070, millet Rs. 0.041, brassica Rs. 0.042, arugula Rs. 0.036 and guar Rs. 0.119 million per hectare. High income from the guar was due to high price of guar grain in the international market during 2012. Generally, the farmers of study area obtained high income from gram crop cultivated by the spate irrigation. The benefit cost ratio of crops determined from income and cost of production is given in Table 13.

Table 13. Benefit cost ratio of the crops.

\begin{tabular}{lcccc}
\hline Crops & $\begin{array}{c}\text { No. of } \\
\text { respondents }\end{array}$ & Minimum & Maximum & Mean \\
\hline Cotton & 07 & 0.98 & 1.51 & 1.29 \\
Wheat & 26 & 0.98 & 2.21 & 1.50 \\
Onion & 11 & 1.05 & 2.01 & 1.57 \\
Gram & 31 & 0.65 & 4.62 & 2.00 \\
Sorghum & 23 & 1.57 & 3.43 & 2.39 \\
Millet & 17 & 0.71 & 2.31 & 1.63 \\
Brassica & 11 & 0.98 & 2.40 & 1.67 \\
Arugula & 02 & 1.40 & 1.59 & 1.49 \\
Guar & 02 & 1.30 & 3.14 & 2.22 \\
\hline
\end{tabular}

The BCR of cotton, wheat, onion, gram, sorghum, millet, brassica, arugula and guar were 1.29, 1.50, 1.57, 2.00, 2.39, $1.63,1.67,1.49$ and 2.22 , respectively. The crops cultivated using canal water and/or groundwater had less BCR than that of the crops cultivated by the spate irrigation. The maximum BCR of guar was due to high prices of guar grains during the study period but normally the BCR of gram remained higher than that of other crops. Therefore, the gram crop was considered a major valuable crop of study area cultivated by the spate irrigation.

Conclusions: The use of spate irrigation improved the cropping intensity of study area but the irrigation efficiency and water productivity of spate irrigated fields were less than that of canal water and/or groundwater irrigated fields. This was mainly due to excessive ponding $(0.61-1.68 \mathrm{~m})$ in case of spate water and low yield than potential due to various stresses during crop growth period. While, the benefit cost ratio of spate irrigated crops was higher (i.e. about 2.0) than that of canal water and/or groundwater irrigated crops (i.e. about 1.45 ) because of less investment and more income from spate irrigated crops. Therefore, it may be concluded that the efficient utilization of hill torrent for spate irrigation through proper channelization, permanent construction of diversion structures, application of optimum depth of water to the bund(s) and subsequent moisture conservation practices would improve the cropping intensities, irrigation efficiency, yield and BCR, and hence the socio economic conditions of the farmers in the study area. Also, the efficient use of hill torrent water resources for spate irrigation would minimize the dependence on canal water and groundwater irrigation in the study area.

\section{REFERENCES}

Ahmad, I. 2012. Gilani for talking up hill torrents water management programme, Pakistan Observer, June 1, 2012.

Ahmad, M. and M.R. Choudhry. 2005. Farmers' irrigation practices under Rod Kohi irrigation system. Pak. J. Water Resour. 9:25-33.

Ahmad, S. 2007. Land and water resources of Pakistan-a critical assessment. The Pakistan Development Review 46: 4 Part II, 911-937.

Arnold, T. 2006. Crop growth module: Capturing crop yield response to water deficit within MPMAS, Mathematical Programming Multi-Agent System Modeling: An Application to Water Resource Management. Institute for Agricultural Economics and Social Sciences in the Tropics and Subtropics, University of Hohenheim.

Baig, M.B., S.A. Shahid and G.S. Straquadine. 2013. Making rainfed agriculture sustainable through environmental friendly technologies in Pakistan: A review. Inter. Soil \& Wat. Conser. Res. 1:36-52.

Frenken, K. 2012. Irrigation in Southern and Eastern Asia in figures AQUASTAT Survey - 2011, FAO Water Report 37, Rome.

Hasan, L. 2008. An anatomy of state failures in the forest management in Pakistan. Pakitan Institute of Development Economics, MPRA Munich Personal RePEc Archive. pp.1-21.

I\&PD. 2002. Master plan of flood management of DG Khan and Rajanpur hill torrents. Project Circle (Irrigation), DG Khan.

Javed, M.Y., M. Nadeem and F. Javed. 2007. Pakistan: additional works for the preparation of hill torrent management plan. Technical Assistance Consultant's Report, Irrigation and Power Deptt., Punjab, Islamabad, Pakistan.

Mirjat, M.S., A.G. Soomro, K.H. Mirjat, M.U. Mirjat and A.S. Chandio. 2011. Potential of hill-torrent spate irrigation in the Kohistan Areas of Sindh: A case study. Pak. J. Agri., Agril. Engg., Vet. Sci. 27:100-114.

Raza, M.A., M. Ashfaq and I.A. Baig. 2009. Institutional reforms in irrigation sector of Punjab (Pakistan) and their impact on sugarcane productivity. J. Agri. Res. 47:63-72.

Steenbergen, F.V., O. Verheijen, S.V. Aarst and A.M. Haile. 2008. Spate irrigation, livelihood improvement and adaptation to climate variability and change. IFAD/ MetaMeta/UNESCO-IHE. Available online at http://www.sswm.info/sites/default/files/reference_attac hments/STEENBERGEN\%20et\%20al\%20ny\%20Spate $\%$ 20Irrigation.pdf

Sufi, A.B., Z. Hussain, S.J. Sultan and I. Tariq. 2011. Integarted water resource management in Pakistan. International Conference on Water Resources 
Engineering \& Management (ICWREM-March 7-8, 2011), UET, Lahore, Pakistan.

UN. 2011. Population facts. Department of Economic and Social Affairs, Population Division.

WAPDA. 2013. Hydro potential in Pakistan. Pakistan Water and Power Development Authority.
Wasti, S.E. 2013. Pakistan Economic Survey 2012-13. Ministry of Finance, Government of Pakistan, Islamabad-Pakistan.

Wasti, S.E. 2014. Pakistan Economic Survey 2013-14. Ministry of Finance, Government of Pakistan. 